\title{
Efecto de inoculantes biológicos sobre la comunidad bacteriana rizosférica y el crecimiento de plantas de maní y maíz
}

\author{
Anzuay, María S.*(1); Angelini, Jorge G. ${ }^{(1)}$; Taurian; Tania ${ }^{(1)}$ \\ ${ }^{(1)}$ Universidad Nacional de Río Cuarto. Río Cuarto. Córdoba. Argentina. \\ *E-mail: manzuay@exa.unrc.edu.ar
}

Introducción: Argentina es uno de los principales productores y el primer exportador mundial de maní (Arachis hypogaea L.). Gran parte de esta producción (90\%) tiene lugar en la provincia de Córdoba dónde ésta fabacea habitualmente se siembra en rotaciones con el cultivo de maíz (Zea mays L.). En los últimos años, los suelos agrícolas han sufrido deterioro como consecuencia de prácticas agrícolas intensivas. La productividad de estos suelos depende, en parte, de los procesos funcionales de las comunidades microbianas del suelo. Un considerable número de especies bacterianas, la mayoría asociadas a la rizósfera de las plantas, son capaces de ejercer un efecto beneficioso para el crecimiento de las mismas. Estas bacterias se asocian en el nicho rizosférico con plantas de interés agronómico y pueden producir efectos directos sobre su crecimiento y nutrición. Entre los mecanismos de promoción del crecimiento vegetal se incluyen fijación biológica de $\mathrm{N}_{2}$ y solubilización/mineralización de fosfatos aportando $\mathrm{N}$ y $\mathrm{P}$ a las plantas, respectivamente. La formulación y aplicación a campo de inoculantes biológicos es de gran importancia en una agricultura sustentable. El objetivo de este trabajo es analizar el efecto de la aplicación de los inoculantes biológicos sobre la comunidad microbiana del suelo y el crecimiento de plantas de maní y maíz en ensayos de microcosmo.

Materiales y métodos: Se realizaron ensayos de inoculación bacteriana de plantas de maní y maíz en macetas utilizando como soporte suelo proveniente del área manisera de Córdoba. Se realizaron dos determinaciones del ensayo y cada una constó de 5 réplicas por tratamiento. Se utilizaron inoculantes bacterianos comerciales y elaborados en nuestro laboratorio con bacterias nativas de maní promotoras del crecimiento vegetal. Tratamientos: Plantas de maní inoculadas con: 1.Cepa de referencia Bradyrhizobium sp. SEMIA 6144; 2. cepa nativa Serratia sp. J260; 3. cepa nativa Enterobacter sp. J49; Plantas de maní 4. fertilizadas con compuestos fosforados y nitrogenados (MicroEssentials ${ }^{\circledR}$ SZ ${ }^{\mathrm{TM}}$ (Mosaic) granulado - 88 $\mathrm{kg} / \mathrm{ha}$ ); 5. sin fertilizar y sin inocular. Plantas de maíz inoculadas con: 1. Inoculante comercial "Rizofos liq Maíz" y Nodumax ${ }^{\circledR}$ Azo maíz; 2. cepa nativa Serratia sp. J260; 3. cepa nativa Enterobacter sp. J49; Plantas de maíz 4. fertilizadas con compuestos fosforados y nitrogenados (MicroEssentials ${ }^{\circledR}$ SZ ${ }^{\mathrm{TM}}$ (Mosaic) granulado - $120 \mathrm{~kg} / \mathrm{ha}$ ); 5. sin fertilizar y sin inocular. Las plantas fueron crecidas en cámara de cultivo vegetal durante 120 y 100 días para maní y maíz, respectivamente. Para determinar el efecto de los tratamientos sobre las comunidad microbianas del suelo se tomaron muestras de suelo rizosférico de las macetas al final del ensayo. El análisis de la abundancia de las poblaciones bacterianas cultivables heterotróficas totales (BCT), fijadoras de $\mathrm{N}_{2}$ (BFN) y solubilizadoras de fosfato (BSP) se realizó mediante diluciones seriadas de las muestras de suelo rizosférico que fueron sembradas en placas conteniendo medio sólido TSA $10 \%$ (tripteína soya agar), medio malato semisólido libre de nitrógeno $(\mathrm{NFb})$ y medio sólido NBRIP-BPB, respectivamente. Con el fin de analizar el efecto de los tratamientos sobre el crecimiento de plantas de maní y maíz, se determinaron al finalizar el ensayo los siguientes parámetros de crecimiento vegetal: longitud aérea y radical, peso seco aéreo y radical, contenido de clorofila y contenido de $\mathrm{P}$ y $\mathrm{N}$ de la parte aérea. Además, se analizaron propiedades físico-químicas del soporte: contenido de $\mathrm{N}$, P, materia orgánica y $\mathrm{pH}$ del suelo.En plantas de maní se analizó también la presencia y número de nódulos y cajas. Los datos experimentales fueron analizados empleando el análisis de la varianza considerando diferencia significativa un nivel $\mathrm{p}<0.05$.

Resultados: Los resultados obtenidos indicaron un incremento en la abundancia de las BSP en la rizósfera de plantas de maní con todos los tratamientos analizados. La inoculación de esta Fabaceacon Enterobacter sp. J49 y el tratamiento fertilizado con P y N, incrementaron también la abundancia de las BCT y BFN. Por otro lado, en las muestras rizosféricas de plantas de maíz se observó un aumento significativo en la abundancia de las tres poblaciones analizadas con todos los tratamientos.

El análisis del efecto de los tratamientos sobre el crecimiento vegetal, el contenido de nutrientes en las plantas y las propiedades físico-químicas del soporte, indica que el tratamiento con Enterobacter sp. J49 fue muy eficiente en plantas de maní. Por otro lado, en las plantas de maíz la inoculación con las bacterias seleccionadas no produjo incrementos significativos respecto al control sin fertilizar y sin inocular.

Conclusiones: Los inoculantes biológicos empleados producen modificaciones en la estructura de las comunidades microbianas rizosféricas, las cuales varían con la especie vegetal. La inoculación con la cepa nativa Enterobacter sp. J49 promueve el crecimiento de plantas de maní. 